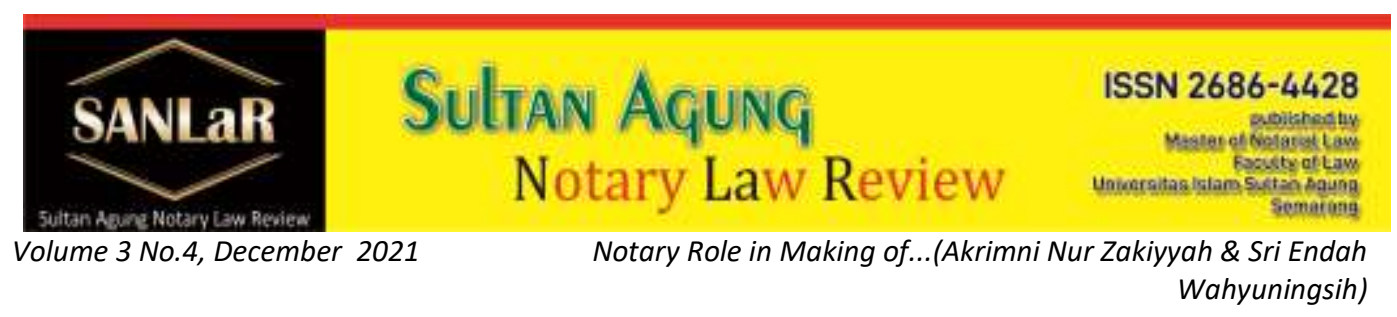

\title{
Notary Role in Making of a Marriage Agreement for A Husband \& Wife Couple in Divorce
}

\author{
Akrimni Nur Zakiyyah*) and Sri Endah Wahyuningsih ${ }^{* *}$ \\ ${ }^{*}$ Faculty of Law, Universitas Islam Sultan Agung (UNISSULA) Semarang, E-mail: \\ zia.cuim@gmail.com \\ ${ }^{* *}$ Faculty of Law, Sultan Agung Islamic University (UNISSULA) Semarang, E-mail: \\ endah.w@unissula.ac.id
}

\begin{abstract}
The existence of the institution of marriage is to legalize the legal relationship between a man and a woman. Due to the very important consequences of marriage, society needs a regulation of living together, namely regarding the conditions for the inauguration, implementation, continuation and termination of living together. However, it is unfortunate that many people in their domestic life end up in divorce. This is what people often use as the only way to end domestic conflicts, so that it has a negative impact on children or one of the divorced couples.Based on this description, this study aims to find out and analyze how the role of a notary in making a marriage agreement deed for a husband and wife in divorce and analyze how the function of a marriage agreement in a husband and wife in divorce. The research method in this thesis uses a sociological juridical approach with descriptive research specifications. Data sources and data collection methods used primary and secondary data which were analyzed qualitatively. The results of this study indicate that the authority of a notary in carrying out his duties and position as a notary is to make an authentic deed. The function of the marriage agreement deed in divorce is to respect and appreciate the dignity of each party and to ensure that there are limits to the rights and obligations that must be carried out by husband and wife, but in marriage there are provisions for the distribution of assets if a problem occurs in the future. if the parties wish that the joint property be included in the joint decision with a divorce dispute, the results to be obtained are for peace and the examination does not require many stages of examination as the examination of marital property in general which is not related or bound by a marriage agreement.
\end{abstract}

Keywords: Agreement; Divorce; Marriage. 


\section{Introduction}

Marriage is a very important institution in society. The existence of the institution of marriage is to legalize the legal relationship between a man and a woman. Due to this very important consequence of marriage, society needs a regulation of living together, namely regarding the conditions for the inauguration, implementation, continuation and termination of living together. Act No. 1 of 1974 states that marriage is an inner and outer bond between a man and a woman as husband and wife with the aim of forming a happy and eternal family (household) based on God Almighty. ${ }^{1}$

Conflict in the family can be caused by several factors, such as economy, living environment, family background from both male and female sides, unwanted interference from father, mother and other family members, the presence of third party interference, and other causes. ${ }^{2}$ The more conflicts that occur, then the relationship between husband and wife communication in the household will be even more difficult executed, unless one of the two can relent or both can get through the problems they face. Nevertheless, it's a shame that not a few people navigate home life the ladder ends in divorce.

Each individual is free to make agreements with other individuals to achieve the desired goals. The parties who want to make an agreement are free to determine the form of the agreement, the content of the agreement and the terms of the agreement. However, so that the agreement is valid and can be used as strong evidence, the parties must make an agreement before a notary so that the deed of agreement becomes a notarial deed. In making a notarial agreement deed, the notary must pay attention to things that do not violate the laws and regulations, public order, and decency. ${ }^{3}$

Article 51 of the Compilation of Islamic Law $(\mathrm{KHI})$ stipulates that if the marriage agreement or Taklik Talak is violated, then the right to request an annulment of the marriage or submit it as a reason for a divorce lawsuit to the Religious Court. According to Law no. 1 of 1974 and $\mathrm{KHI}$, the cancellation or cancellation of a marriage agreement

Thus, both of them are finally faced with divorce which is the final way if it is not found by the way both (husband and wife) to reconcile. Although here divorce is

\footnotetext{
${ }^{1}$ R.Wirjono Prodjodikoro, (1974), Hukum Perkawinan di Indonesia, print. 6, Jakarta: Sumur Bandung, p. 7.

${ }^{2}$ Ibrahim Amini, (1996), Bimbingan Islam untuk Kehidupan Suami Istri, Bandung: Al-Bayan, p. 11

${ }^{3}$ Ogi Hanapiah, Sigit Prihanto,Sri Endah Wahyuningsih. "Hal-Hal Yang Perlu Diperhatikan Oleh Notaris Dalam Membuat Akta Perjanjian Notariil”. Jurnal Akta. Vol. 5, No. 1, January, 2018
} 
the last resort to resolve conflicts in a marriage. So it is necessary to know the position of the marriage agreement in the divorced couple.

\section{Research Methods}

The method used in this research is a sociological juridical approach. The sociological juridical approach is an approach by looking at a legal reality in society. ${ }^{4}$ The sociological juridical approach emphasizes research with the aim of obtaining legal knowledge empirically by going directly to the object, namely knowing the role of a notary in making a marriage agreement for a husband and wife pair in a divorce case study at the Semarang District Court. Sociological research is carried out by researching the field which is a secondary material. The research specification used in this research is descriptive research. Descriptive research is research that only describes the phenomenon of an event or events that occur in the object of research which is then analyzed to obtain conclusions ${ }^{5}$.

\section{Results and Discussion}

\subsection{The Role of the Notary in Making the Marriage Agreement}

The basis of the Notary's authority in carrying out his duties and position as a notary to make an authentic deed in this case the marriage agreement deed is regulated in the Law of the Republic of Indonesia Number 2 of 2014 on the amendment of Act No. 30 of 2004 concerning the position of a Notary Article $15^{6}$. The explanation in this article provides a clear picture of the authority of a notary in carrying out the task of making an authentic deed for the parties, be it a marriage agreement deed or other authentic deeds. After the Decision of the Constitutional Court No. 69/PUU-XIII/2015 concerning the basis for making a marriage agreement that can be made before and after the marriage takes place.

The decision of the Constitutional Court No.69/PUU-XIII/2015 is jurisprudence which is one of the sources of law. Jurisprudence is a decision that has permanent legal force (inkracht van gewijsde) and the decision of the Constitutional Court (MK) is final and binding.

In making a marriage agreement, a Notary can use the provisions contained in

\footnotetext{
${ }^{4}$ Soejorno Soekanto, (1998), Pengantar Penelitian Hukum. Jakarta: UI Press. p. 51.

${ }^{5}$ A Chuasanga, Ong Argo Victoria. (2019). Legal Principles Under Criminal Law in Indonesia and Thailand, Jurnal Daulat Hukum, Vol 2, No 1 (2019) http://jurnal.unissula.ac.id/index.php/RH/article/view/4218 see to Deen, Thaufiq., Ong Argo Victoria \& Sumain. (2018). Public Notary Services In Malaysia. JURNAL AKTA: Vol. 5, No. 4, 10171026. Retrieved from http://jurnal.unissula.ac.id/index.php/akta/article/view/4135

${ }^{6}$ Decision of the Constitutional Court (MK) No. 69/PUU-XIII/2015
} 
the Civil Code (KUHPerdata) or follow the provisions contained in the Constitutional Court Decision (MK) No. 69/PUU-XIII/2015 concerning amendments to Article 29 of Law No.1 of 1974 which allows marriage agreements to be made before and after the occurrence of marriage as long as it is still in marriage. The notary and the parties are given freedom of choice in making a marriage agreement as long as it is not detrimental to third parties or the notary ${ }^{7}$.

The parties who make the marriage agreement are bound by the agreement that applies as law. The role of the Notary in making the marriage agreement deed as the official making the Notary Deed or the same as the Authentic Deed is perfect and binding for the parties who make it. ${ }^{8}$.

\subsection{Analysis of Legal Certainty and Legal Responsibilities of a Notary in Making a Marriage Agreement}

According to Humberto Avila in his book, Certainty in Law, "Legal certainty means the ability to foresee the legal consequences of facts or behavior in a concrete case". real happen ${ }^{9}$.

Laws are made or formed with the aim of fulfilling taste, justice, certainty, order. Adherents of the flow of positivism dogmatically emphasize the law more on the aspect of legal certainty for legal subjects, namely the bearers of rights and obligations. The agreement as a legal figure must contain legal certainty. This legal certainty is to provide protection for legal subjects in the agreement. This certainty is revealed from the power of binding the agreement itself, namely as a law for the parties who made it, therefore the existence of Article 186 of the Civil Code in the judge's consideration in establishing a marriage agreement after marriage.

According to Hans Kelsen in his theory of legal responsibility, it states that: "a person is legally responsible for a certain act or that he bears legal responsibility, the subject means that he is responsible for a sanction in the case of an act that

\footnotetext{
${ }^{7}$ Ong Argo Victoria, Ade Riusma Ariyana, Devina Arifani. (2020). Code of Ethics and Position of Notary in Indonesia. Sultan Agung Notary Law Review 2 (4), 397-407, http://lppmunissula.com/jurnal.unissula.ac.id/index.php/SANLaR/article/view/13536 see to Yaya Kareng, Ong Argo Victoria, R. Juli Moertiyono. (2019). How Notary's Service in Thailand. Sultan Agung Notary Law $\quad$ Review, 11$)$ 46-56, http://jurnal.unissula.ac.id/index.php/SANLaR/article/view/4435

${ }^{8}$ Interview with Mr. Yogi Arsono as Judge at the Semarang District Court

${ }^{9}$ http://scholar.unand.ac.id/36137/1/BAB\%201.pdf
} 


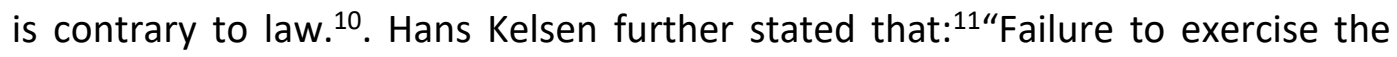
caution required by law is called negligence (negligence) and oversight is usually seen as another type of error (culpa), although not as severe as the error fulfilled by anticipating and wishing, with or without malicious intent, harmful consequences. " Hans Kelsen further divides the responsibility consisting of: ${ }^{12}$

a. Individual responsibility, that is, an individual is responsible against his own offense,

b. Collective responsibility means that an individual is responsible for an offense committed by another person,

c. Liability based on guilt means that a person are responsible for violations committed intentionally and with the intention of causing harm,

d. Absolute liability which means that an individual responsible for the violations committed by accident and unforeseen.

Responsibility in the legal dictionary can be termed as liability and responsibility, the term liability refers to legal responsibility, namely accountability due to mistakes made by legal subjects, while the term responsibility refers to political responsibility. ${ }^{13}$ The theory of responsibility emphasizes more on the meaning of responsibility that is born from the provisions of the legislation so that the theory of responsibility is interpreted in the sense of liability. ${ }^{14}$, as a concept related to the legal obligation of a person who is legally responsible for certain actions that he can be subject to a sanction in case his actions are against the law. In the administration of a State and government, accountability is attached to positions which have also been attached to authority. In the perspective of public law, the existence of this authority gives rise to accountability, in line with general principles; "geenbevegdedheid zonder verantwoordelijkheid" there is no authority without responsibility; "la sulthota bila mas-uliyat" (no authority without accountability) ${ }^{15}$.

The role of the Notary in making the marriage agreement deed must be based on the existing laws and regulations. This is to ensure legal certainty and can provide legal accountability both for the parties and for the Notary himself.

\subsection{Functions of the Marriage Agreement Deed for Husband and Wife in Divorce}

\footnotetext{
${ }^{10}$ Hans Kelsen (a) , (2007), translated by Somardi, General Theory Of law and State, Teori Umum Hukum dan Negara, Dasar-Dasar IImu Hukum Normatif Sebagai Ilmu Hukum Deskriptif Empirik, Jakarta: BEE Media Indonesia, p. 81

${ }^{11}$ Ibid, p. 83

${ }^{12}$ Hans Kelsen (b), (2006), translated by Raisul Mutaqien, Teori Hukum Murni, Bandung: Nuansa \& Nusa Media, p. 140.

${ }^{13}$ HR. Ridwan, (2006), Hukum Administrasi Negara, Jakarta: Raja Grafindo Persada, p. 337.

${ }^{14}$ Busyra Azheri, (2011), Corporate Social Responsibility dari Voluntary menjadi Mandotary, Jakarta: Raja Grafindo Perss, p. 54

${ }^{15}$ Ibid, p. 352
} 
Marriage agreement according to the legislation (the Civil Code and Act No. 1974 concerning Marriage). In the Civil Code (BW) regarding marriage agreements are generally specified in Articles 139 to 154. In Article 139 it is stated that, "by entering into a marriage agreement, both prospective husband and wife are entitled to prepare some deviations from the statutory regulations regarding the union of assets. , as long as the agreement does not violate good morals or general rules and as long as all the provisions below are observed according to the next article "16

The Civil Code requires that the marriage agreement must be made notarially, including the amendments, otherwise the marriage agreement is threatened with being null and void by law. In Article 147 of the Civil Code, among other things, it is stated that under the threat of cancellation, every marriage agreement must be made with a notary deed before the marriage takes place. Furthermore, in the provisions of Article 148 of the Civil Code, among others, it states that all changes to the marriage agreement cannot be carried out in another way, but by a deed and in the same form as the marriage agreement that was previously made. ${ }^{17}$ Functions of the Marriage Agreement in Divorce

\section{a. Freedom of Action}

The marriage agreement, which is a separation of assets, each has freedom of property obtained during the marriage, is free to take legal actions against third parties on the property owned and is also free to use his property.

\section{b. Work Improvement}

With the marriage agreement in the form of separation of assets, each party can own and fully control the assets produced. This will have an impact on increasing work to work and take business actions, because in the eyes of the law if you don't have your own job, then you don't have rights to the assets owned by your husband and vice versa, and if there is a divorce, the wife will lose her husband and have no rights. other things to sustain life in the future so that the parties, both husband and wife, will be encouraged to do work where it is for their own good and interests to own the property as a whole. ${ }^{18}$.

A marriage agreement is defined as a legal relationship regarding assets between two parties, where one party promises or is deemed to have promised to do something, while the other party has the right to demand the

\footnotetext{
${ }^{16}$ Hilman Hadikusuma, (2007), Hukum Perkawinan Indonesia, Bandung: Mandar Maju, p.52

${ }^{17}$ Rachmadi Usman, Op. Cit., p. 287

18 Interview with Mr. Yogi Arsono, Semarang District Court Judge
} 
implementation of the promise. ${ }^{19}$

Prospective husbands and wives who before the marriage or during the marriage take place can make a marriage agreement other than the joint property regulations as long as it does not conflict with good moral code or general rules that apply.

The marriage agreement is made to respect and appreciate the dignity of each party and to ensure that there are limits to the rights and obligations that must be carried out by husband and wife, but in marriage there are provisions for the distribution of assets in the event of a problem in the future and provisions in the event of negligence in providing rights that must be accepted by the wife and children, so that there is peace and legal certainty for the wife in marriage. The marriage agreement can ensure the separation of inheritance from the wife. With the division of separation and restrictions on the assets so as to lead to a calm life without any disputes and disputes, and no one feels disadvantaged from the distribution of these assets.

\subsection{Analysis of the Binding Strength of the Marriage Agreement in Divorce}

The theory of binding force is also known as pacta sunt servanda, that agreement will act as law for the parties who make it. This theory is contained in Article 1338 of the Civil Code, where it is stated that "all agreements made legally apply as law for those who make them". Each party who is bound and bound in an agreement must respect and carry out what they have agreed and are not allowed to commit acts that deviate or conflict with the contents of the agreement they have made. ${ }^{20}$

The parties who are bound in the agreement are not only limited to the contents of the agreement that have been made but also to several other elements as long as it is desired by customs and decisions as well as morals. ${ }^{21}$. Thus the marriage agreement is the same as any other agreement, and will apply as law and bind the parties who made it, which in this case is husband and wife or there is a third party in the agreement.

The power of binding a notarial deed is how the marriage agreement is made in the form of a notarial deed. Notary deed is a deed made and read and signed in front of a notary. The contents of the deed are the wishes of the parties but as a

19 H.A Damanhuri, (2012), Segi-Segi Hukum Perjanjian Perkawinan Harta Bersama, Bandung: Mandarmaju, p.14

${ }^{20}$ Harlien Budiono, (2010), Ajaran Umum Hukum Perjanjian dan Penetapan di Bidang Hukum Kenotariatan, Bandung: Citra Aditya, p. 174

${ }^{21}$ Mariam Darus Badrulzaman, (2001), Komplikasi Hukum Perikatan, Bandung: Citra Aditya Bakti, p. 87 
public official, the Notary is fully responsible for the contents of the deed regarding the truth and the provisions contained in it, guaranteeing the date and the person or parties who signed the deed are competent persons. There are several contents of the marriage agreement which are included in the deed made before a Notary including:

\section{a. Marriage Agreement for Separation of Assets}

It means a marriage agreement made by husband and wife where it is determined that in their marriage there is no unity of property or in other words there is no joint property that arises as a result of husband and wife marriage.

\section{b. Profit and Loss Union Marriage Agreement}

The intent contained in the profit and loss union agreement is that each husband and wife will maintain their property, either in the form of innate personal assets or in the form of gifts specifically intended for each party and/or the rights assigned to them. have been granted laws, such as inheritance, grants and wills. Meanwhile, all income earned from labor or capital during the marriage becomes joint property. Vice versa, all losses suffered in fulfilling the needs of married life as husband and wife become a loss and a shared burden.

\section{c. Income Union Marriage Agreement}

The income result union agreement is an agreement between the prospective husband and wife to unite every profit (results and income) only. This agreement means similar to a "profit agreement" only whereas all losses are not agreed upon. In this case, Wirjono Prodjodikoro stated that, "The wife is only responsible for the losses suffered as a result of her own actions. ${ }^{22}$.

\subsection{The Power of Binding the Marriage Agreement in Divorce}

If the marriage agreement made by husband and wife after recording the marriage has been carried out in a notarial and authentic deed to obtain perfect strength of evidence, then the marriage agreement is binding both to the husband and wife themselves and to third parties involved in it. Therefore, a marriage agreement must be made and stated in a notarial deed and then recorded on the margins of the column of the husband and wife's marriage certificate and the marriage agreement is then reported to the population office in the area where the husband and wife reside. The types of marriage agreement deeds that can be made at the Notary's office by husband and wife in their marriage are:

\footnotetext{
${ }^{22}$ Wirjono Prodjodikoro, Op.Cit., p. 121
} 


\section{a. Marriage Agreement with Total Separation of Assets}

b. Marriage Agreement with Profit and Loss Union

\section{c. Marriage Agreement with Union and income}

According to the Marriage Law, a marriage agreement can bind a third party if it has complied with the provisions contained in Article 29 paragraph (1) which reads: "At or before the marriage takes place, both parties under a collective agreement can enter into a written agreement ratified by the Marriage Act. a marriage registrar, after which the contents also apply to third parties as long as a third party is involved." Meanwhile, post-marriage registration marriage agreements made on the basis of a district court determination referring to Article 1338 of the Civil Code states that a marriage agreement based on an agreement from husband and wife is binding as if it were a marriage registrar. the law for husband and wife who make it.The assumption that third parties do not know about the existence of a marriage agreement can only be given to third parties who do not know that husband and wife have made a marriage agreement but have not registered it.

Meanwhile, a third party who knows that the husband and wife have made a marriage agreement but the marriage agreement has not been registered, then he must not assume that the marriage agreement does not exist and the husband and wife enter into a marriage with the union of marital property. So if the marriage agreement is not registered in accordance with the provisions of the applicable laws and regulations, the marriage agreement remains valid for husband and wife. It is different if it is involved in a third party, if the marriage agreement is not registered as regulated in the applicable laws and regulations, the legal consequences of the marriage agreement do not have binding force. ${ }^{23}$.

Marriage agreements can help the parties to resolve disputes that occur in the household and can also help settle cases in court, namely:

a. For the parties who have been bound in the marriage agreement

Even though in this case a dispute over joint property arises, the judge will check whether it is true that the two litigants have been bound by the marriage agreement. the need for a local examination and will immediately refer to the marriage agreement, in accordance with the demands of the parties from the contents of the marriage agreement. In terms of examining cases on marriage agreements, the panel of judges does not focus on the rights of joint assets that must be accepted by each litigant, disputes over marriage agreements are more

${ }^{23}$ https://media.neliti.com/media/publications/242914-power-binding-akta-notariil-percepatan 
directed to the denial or default of the agreement or misuse of the property that has been agreed, in In this case the parties who are dissatisfied can file an appeal or come to an appeal, the examination is still easier than the absence of a marriage agreement on the parties, the essence of the problems that arise and be examined will be simpler with the existence of a marriage agreement compared to the absence of an agreement marriage.

\section{b. Cost Saving}

In household disputes that have been bound by a marriage agreement, it can be in the form of assets obtained during the marriage not to be processed in court, because between husband and wife or third parties who are bound by the property have fully realized and accepted the agreement, and if the parties requires that joint assets be included in the joint decision with divorce disputes, the results to be obtained are for peace and the examination does not require many stages of examination as the examination of marital property in general which is not related or bound by a marriage agreement. ${ }^{24}$

\section{Conclusion}

The role of the Notary in making the marriage agreement deed as the official making the Notary Deed or the same as the Authentic Deed is perfect and binding for the parties who make it. The function of the marriage agreement deed in divorce. The marriage agreement is made to respect and appreciate the dignity of each party and to ensure that there are limits to the rights and obligations that must be carried out by husband and wife. The marriage agreement can also ensure the separation of inheritance from the wife. With the division of separation and restrictions on the assets so as to lead to a calm life without any disputes and disputes, and no one feels disadvantaged from the distribution of these assets. Marriage agreements can help the parties to resolve disputes that occur in the household and can also help settle cases in court, namely: For the parties who have been bound in the marriage agreement, even though in this case a dispute over joint property arises, the judge will check whether it is true that the two litigants have been bound by the marriage agreement and Cost Saving term.

\section{References}

Journals:

[1] A Chuasanga, Ong Argo Victoria. (2019). Legal Principles Under Criminal Law in Indonesia and Thailand, Jurnal Daulat Hukum, Vol 2, No 1 (2019) http://jurnal.unissula.ac.id/index.php/RH/article/view/4218

${ }^{24}$ HA Damanhuri, Op.cit. p. 14 
[2] Deen, Thaufiq., Ong Argo Victoria \& Sumain. (2018). Public Notary Services In Malaysia. JURNAL AKTA: Vol. 5, No. 4, 1017-1026. Retrieved from http://jurnal.unissula.ac.id/index.php/akta/article/view/4135

[3] Ogi Hanapiah, Sigit Prihanto,Sri Endah Wahyuningsih. "Hal-Hal Yang Perlu Diperhatikan Oleh Notaris Dalam Membuat Akta Perjanjian Notariil". Jurnal Akta. Vol. 5, No. 1, January, 2018

[4] Ong Argo Victoria, Ade Riusma Ariyana, Devina Arifani. (2020). Code of Ethics and Position of Notary in Indonesia. Sultan Agung Notary Law $\begin{array}{lllll}\text { Review } & 2 & (4), & \text { 397-407, } & \text { http://lppm- }\end{array}$ unissula.com/jurnal.unissula.ac.id/index.php/SANLaR/article/view/13536

[5] Yaya Kareng, Ong Argo Victoria, R. Juli Moertiyono. (2019). How Notary's Service in Thailand. Sultan Agung Notary Law Review, 1 (1), 46-56, http://jurnal.unissula.ac.id/index.php/SANLaR/article/view/4435

Books:

[1] Busyra Azheri, (2011), Corporate Social Responsibility dari Voluntary menjadi Mandotary, Jakarta: Raja Grafindo Perss

[2] H.A Damanhuri, (2012), Segi-Segi Hukum Perjanjian Perkawinan Harta Bersama, Bandung: Mandarmaju

[3] Hans Kelsen (a) , (2007), translated by Somardi, General Theory Of law and State, Teori Umum Hukum dan Negara, Dasar-Dasar IImu Hukum Normatif Sebagai Ilmu Hukum Deskriptif Empirik, Jakarta: BEE Media Indonesia

[4] Hans Kelsen (b), (2006), translated by Raisul Mutaqien, Teori Hukum Murni, Bandung: Nuansa \& Nusa Media

[5] Harlien Budiono, (2010), Ajaran Umum Hukum Perjanjian dan Penetapan di Bidang Hukum Kenotariatan, Bandung: Citra Aditya

[6] Hilman Hadikusuma, (2007), Hukum Perkawinan Indonesia, Bandung: Mandar Maju

[7] HR. Ridwan, (2006), Hukum Administrasi Negara, Jakarta: Raja Grafindo Persada

[8] Ibrahim Amini, (1996), Bimbingan Islam untuk Kehidupan Suami Istri, Bandung: Al-Bayan

[9] Mariam Darus Badrulzaman, (2001), Komplikasi Hukum Perikatan, Bandung: Citra Aditya Bakti

[10] R.Wirjono Prodjodikoro, (1974), Hukum Perkawinan di Indonesia, print. 6, Jakarta: Sumur Bandung

[11] Soejorno Soekanto, (1998), Pengantar Penelitian Hukum. Jakarta: UI Press.

Regulation: 
Decision of the Constitutional Court (MK) No. 69/PUU-XIII/2015

Internet:

[1] http://scholar.unand.ac.id/36137/1/BAB\%201.pdf

[2] https://media.neliti.com/media/publications/242914-power-bindingakta-notariil-percepatan 